Nordisk Tidsskrift for Kriminalvidenskab 2003

\title{
KRIMINALITET I DANSKE MASSEMEDIER
}

\author{
Af PROFESSOR, DR.PHIL. ANKER BRINK Lund
}

Content analyses covering one week of output from nine television stations and nine newspapers in Denmark show marked discrepancies between mass mediated crime and felonies registered by the police. Television primarily overemphasises murder, armed robberies and other types of violent crimes. Newspapers focus markedly on forgery, fraud, rape and other sexual offences. Misdemeanours are reported by local press only. All in all 1,210 crimes were detected in the television channels analysed. Disregarding sports, weather reports and trailers this amounts to one or more crimes depicted in 16\% of the TV programmes examined. Only 5\% of the news items, however, included reference to criminal acts, and most crime fiction was televised before or after prime time indicating its relatively lower priority in Danish media as compared to British and American crime coverage. The newspaper sample included national broadsheets, popular tabloids and local papers. 1,230 crimes were detected, i.e. criminal acts occur in 14 percent of articles published during the week analysed. With the exception of one tabloid, the newspapers reported most of these incidents in small announcements indicating a relatively low editorial priority. Our conclusion is that current media criticism misses crucial points by excessive concern for moral panics and spectacular hype rather than routine news coverage and crime as entertainment. Detailed analyses of dominant media prototypes, i.e. stories on injustice, self-help, risk and curiosities, should qualify current debates on mass mediated delinquency - including trends towards mixing facts and fiction in so called reality shows. This effort calls for closer cooperation between criminologists and mass media researchers. *

Medier og kriminalitet er en sprængfarlig cocktail, som mange har skråsikre meninger om. Desværre har de færreste forskningsbaseret grund under fødderne, når sådanne domme fældes. Debatten er ofte følelsesladet og baseret på spektakulære enkeltsager. Det gælder i hvert fald for Danmarks vedkommende, hvor massemediernes kriminalstof kun i meget begrænset omfang er gjort til genstand for systematisk udredning.

Udenlandske studier (Dalquist, 1998; Cronström, 1999; Erstad, 1998; Gadd, 1994; Goode \& Ben-Yehuda, 1994; Høst \& Bodahl-Johansen, 2001; Schlesinger \& Tumber, 1994; Pollack, 2001; Walma et al., 2002) er ikke nødvendigvis

* Title in English: Criminality in Danish Mass Media. Original in Danish. 
umiddelbart relevante i en konkret dansk sammenhæng, blandt andet fordi mediestruktur og kriminalitetsmønster ikke er identiske på tværs af tid og rum. Det forekommer derfor nyttigt konkret at kortlægge, hvordan formidlingen af forbrydelser og kriminelle faktisk finder sted i en afgrænset periode gennem et repræsentativt udvalg af danske massemedier. Derved kan der lægges op til en fordomsfri diskussion af disse spørgsmål:

- Hvor meget kriminalitet findes i forskellige medie-typer?

- Hvordan svarer mediebilledet til den anmeldte kriminalitet?

- Definerer medie-kriminalitet den retspolitiske dagsorden?

- Er der tale om uforpligtende underholdning?

Vi har ved Syddansk Universitet valgt at analysere problematikken komparativt ved at anvende tre forskellige datakilder - alle indsamlet i uge 46,2002, det vil sige perioden 11.-17. november Der er for det første tale om selektive stikprøver i de ni tv-kanaler, som bringer danske undertekster på importerede programmer. For det andet er der foretaget systematisk indholdsanalyse af ni danske dagblade, der omfatter både landsdækkende omnibusaviser, tabloid-dagblade, trafikaviser og lokalaviser. Til sammenligning har Rigspolitichefens statistiske enhed stillet en særkørsel til rådighed fra anmeldelsesregisteret for den pågældende november-uge, 2002.

Erfaringer fra tidligere studier af andre journalistiske stofområder, men med tilsvarende design (Lund, 2000 \& 2002) viser, at tendenser i de udvalgte medieuniverser svarer til den redaktionelle virksomhed i mediestrukturen som helhed. Således skulle der være tilvejebragt et nogenlunde repræsentativt datagrundlag for danskernes rutineprægede mediebrug. Dog må det bemærkes, at radiomediet, fagpressen, internettet, magasinpressen og biografuniverset ikke indgår i undersøgelsen. Ved vurderingen af sammenligningerne må der også tages højde for, at anmeldelsesregistrering ikke nødvendigvis giver det eksakt mål på den faktiske kriminalitet. (note) 
Figur 1. Kriminalitetens top-ti (i procent) prioriteret ved antallet af politianmeldelser sammenlignet med prioritering afforbrydelser itv og dagspresse, uge 46-2002

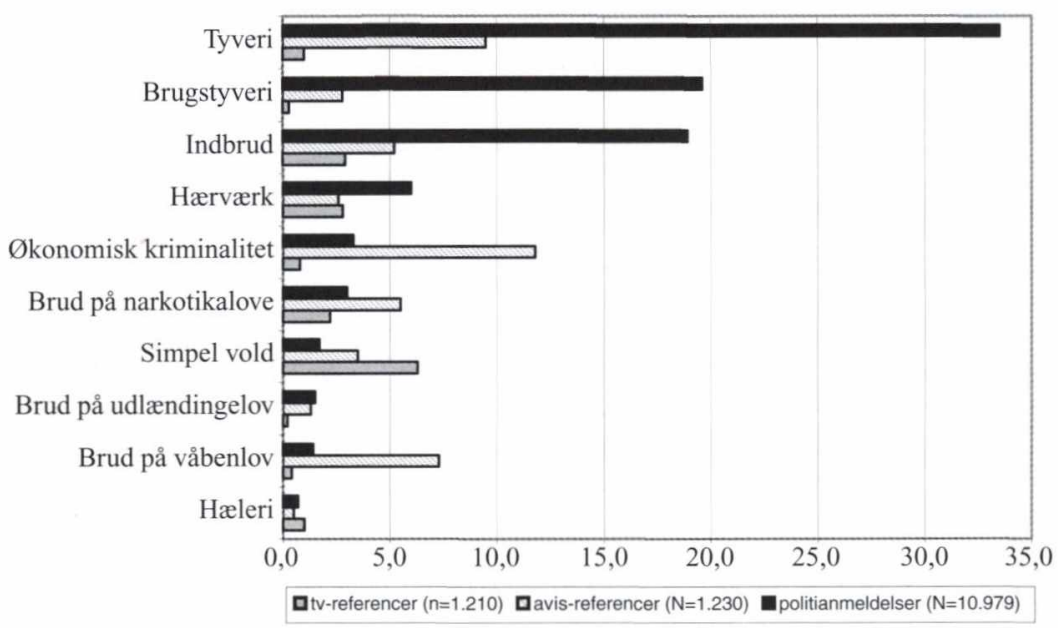

Med disse metodemæssige begrænsninger in mente fremgår det af figur 1, at kriminalitetsprofilen i danske massemedier kun i begrænset omfang afspejler den samtidig kriminalitet i samfundet - målt som antallet af anmeldte forbrydelser. Det er således især tyverier og andre former for berigelseskriminalitet, der dominerer kriminalstatistikken. Den slags hverdagsforbrydelser interesserer tydeligvis medieproducenter væsentligt mindre end andre former for kriminalitet. De forbrydelser, som udgør 90 procent af ugens politianmeldelser, modsvarer samlet set halvdelen af dagbladenes kriminaldækning, men udgør kun 18 procent af den kriminalitet, som formidles af tv-mediet. Bemærk også den redaktionelle fokusering på voldskriminalitet, hvor andelen for tv er elleve gange større end ugens danske politianmeldelser.

Når konkrete sammenligninger af denne art sjældent ligger til grund for aktuel kriminal-debat, hænger det ikke kun sammen med at det er arbejdskrævende at foretage kategorisering og dataindsamling. Det skyldes også meningsdannende traditioner, der forsøger at holde faktuel nyhedsformidling og fiktionaliseret underholdning ude fra hinanden (Lund \& Horst, 1999). Denne skelnen er imidlertid vanskelig af opretholde i praksis, hvilket bl.a. fremgår af de stærkt delte meninger om, hvad vi på forskningsgrundlag kan konkludere om effekten af medievold på publikums virkelighedsopfattelse og sociale adfærd (Clausen, 
2002; Drotner, 2001; Feilitzen, 2001; Mustonen, 1997; Rönnberg, 1998). De data, der fremlægges i det følgende, giver ikke grundlag for at afklare uenigheder om mediedækningens direkte effekt på almenbefolkningen. Til gengæld kan de kvantitative og kvalitative indholdsanalyser belyse, hvordan kriminalstof prioriteres og indgår som konkurrence-parameter i massemediernes kamp om publikums opmærksomhed. Desuden kan vi på forskningsbaseret grundlag vurdere, hvilken indflydelse underholdende mediesager har på den offentlige debat og dermed indirekte på den retspolitiske dagsorden.

\section{Kriminalitet i ni tv-kanaler}

I perioden mandag den 11 . november til søndag den 17 . november 2002 sendte ni dansksprogede tv-kanaler i alt 1.675 programsatte udsendelser. Baseret på systematiske stikprøver skønner vi, at der i disse udsendelser blev begået 1.210 forbrydelser. Når vi ser bort fra sportsudsendelser, vejrmeldingerne og tv-stationernes forskræp for egne udsendelser, giver det i gennemsnit cirka en forbrydelse pr. tv-udsendelse. Men kriminaliteten er her - som i samfundet i øvrigt - ulige fordelt. Alt $i$ alt har vi identificeret kriminelle handlinger i 262 tv-udsendelser svarende til 16 procent af den samlede sendeflade.

Tabel 1. Redaktionelle enheder med kriminelt indhold i ni danske tv-kanaler, uge 46-2002

Nyhedsindslag Dokumentar Fiktion i alt

Public service tv:

$\begin{array}{lcccc}\text { DR1 } & 15 & 6 & 14 & 35 \\ \text { TV2 } & 22 & 3 & 19 & 44 \\ \text { TV2Zulu } & - & 1 & 17 & 18 \\ \text { DR2 } & 2 & 3 & 5 & 10 \\ \text { DK4 } & - & - & - & - \\ \text { Kommercielt tv: } & & & & \\ \text { TV3 } & 9 & - & 14 & 23 \\ \text { TvDanmark2 } & 6 & 10 & 33 & 40 \\ \text { 3+ } & - & - & 20 & 20 \\ \text { TvDanmark1 } & - & 10 & 53 & 63 \\ \text { I alt } & 54 & 33 & 175 & 262\end{array}$

De to publikumstunge public service tv-kanaler, DR1 og TV2, afviger ikke markant fra deres kommercielle konkurrenter, når det gælder dækning af kriminelle forhold: TV2 når i ugen løb op på 22 procent udsendelser, der indeholder kriminelle elementer, og DR1 placerer sig på det gennemsnitlige niveau: 16 procent. Blandt de fem såkaldte public service kanaler, der ikke skal generere et økono- 
misk overskud til ejerne, ligger marginalkanalen DK4 derimod i en klasse for sig. Her har vi ikke identificeret en eneste kriminel handling i hele uge 46. Bemærk også, at DK4 har meget lave seertal - uden at de to forhold sandsynligvis betinger hinanden.

DR og TV2 driver hver sin suppleringskanal, der klart kontrasterer hinanden, når det gælder kriminaldækning. På DR2, der kun formidler forbrydelser i otte procent af udsendelserne, satses der især på det traditionelle mord i britiske omgivelser med midaldrende enspændere i hovedrollerne som ordenshåndhævere. Den slags detektivhistorier er helt fraværende i de 18 procent af udsendelserne, der rummer kriminalitet på TV2s suppleringskanal TV2Zulu. Her satser programlæggerne målrettet på unge seere, og i den sammenhæng står kriminal-underholdning af traditionel art i relativ lav kurs. Vold og forbrydelser indgår mest som biomstændigheder i eksotiske og erotiserede miljøer, hvor der ikke fokuseres på forbrydelser som hovedtema. Det gælder f.eks. serien "Buffy - vampyrernes skræk" og dens mange efterligninger i fiktionsuniverset. Her begås jævnligt drab og voldelige overfald. Men det sker nærmest en passant, som baggrundsstøj for hovedsagen: De unges forsøg på at tilkæmpe sig en identitet med heroiske elementer i en kedsommelig skolehverdag.

På de fem public service kanaler spenderes 70 procent af danskernes tvsening, så alt andet lige er det her en eventuel tv-påvirkning må forventes at være størst. Derfor er det bemærkelsesværdigt, at på dem alle er tidsperioden 19-22:30 (prime time) stort set fri for kriminalitet - bort set fra nogle fă amerikanske spillefilm, enkelte indslag i nyhedsudsendelser og de populære faktionsserier af typen "Station 2" og "Sagen Uopklaret", som følger politiets arbejde med udgangspunkt i rekonstruktion af faktiske kriminalsager.

Målt i seertal har de dansktekstede kanaler uden public service forpligtelser, TV3 og tv-danmark 2, langt mindre gennemslagskraft. Til gengæld må de af kommercielle grunde prioritere deres programudbud endnu mere strategisk end deres helt eller delvis licensfinansierede konkurrenter. I den sammenhæng er det bemærkelsesværdigt, at kriminaliteten holdes nede på nogenlunde samme niveau som hos DR og TV2 og heller ikke primært placeres i prime time. Der er altså ikke noget, der tyder på, at rendyrkede kriminaludsendelser skulle være mere attraktive - anskuet som publikumsmagnet og formidler af reklamer - end tv-programmer uden forbrydelser.

Den bedste aften-sendetid var i den analyserede periode på TV3 primært reserveret til "Robinson-ekspeditionen" og tilsvarende programformater, hvor iscenesat virkelighed udspiller sig i et langt føljeton-forløb. Som kontrast til denne form for reality-show satsede tv-danmark på rekonstrueret virkelighed $\mathrm{i}$ form af dramatiserede dokumentarprogrammer, der bl.a. følger genuine politifolks autentiske jagt på levende (og ind imellem døde) forbrydere - hovedsageligt i amerikanske storbyer under lokkende overskrifter som "Politiets farlige arbejde" og "FBI files". En enkelt dag midt i ugen satses der stort på en dansk 
udgave af genren kaldet "Fornemmelse for Mord". Her hjælper den kommercielle tv-kanal på eget initiativ politiet med opklaring af for længst henlagte sager - assisteret af clairvoiante og andre alternativt begavede detektiver.

De kommercielle kanalers suppleringskanaler afspejler moderkanalernes programprofil ved at rendyrke de allerede beskrevne tendenser. Hvad angår andelen af tv-indslag med forbrydelser slår marginalkanalen Tv-danmark1 alle rekorder. Hele 44 procent af ugens udsendelser på denne kanal rummer en eller flere forbrydelser. Men det afspejler sig ikke i højere seertal, og de fleste tv-serier er af ældre dato (og derfor billige at genudsende), f.eks. "Mission Impossible" og "Pasific Blue".

Tilbage står Kanal 3+, der satser på amerikanske serier af den type, som i de autoriserede programomtaler kaldes "romantiske komedier": situationskomik tilsat dåselatter. Her udelukker genre-konventionerne forbrydelser i traditionel forstand. Den eneste gennemgående tv-serie på 3+, der kan præstere kriminalitet i større omfang, er således den uopslidelige "Lassie på nye eventyr" med vagthunden som bjæffende håndhæver $\mathrm{af}$ lov og orden.

Figur 2. Kriminalitetens top-ti (i procent) prioriteret ved antallet af tv-indslag sammenlignet med politianmeldelser og indslag $i$ dagspressen, uge 46-2002

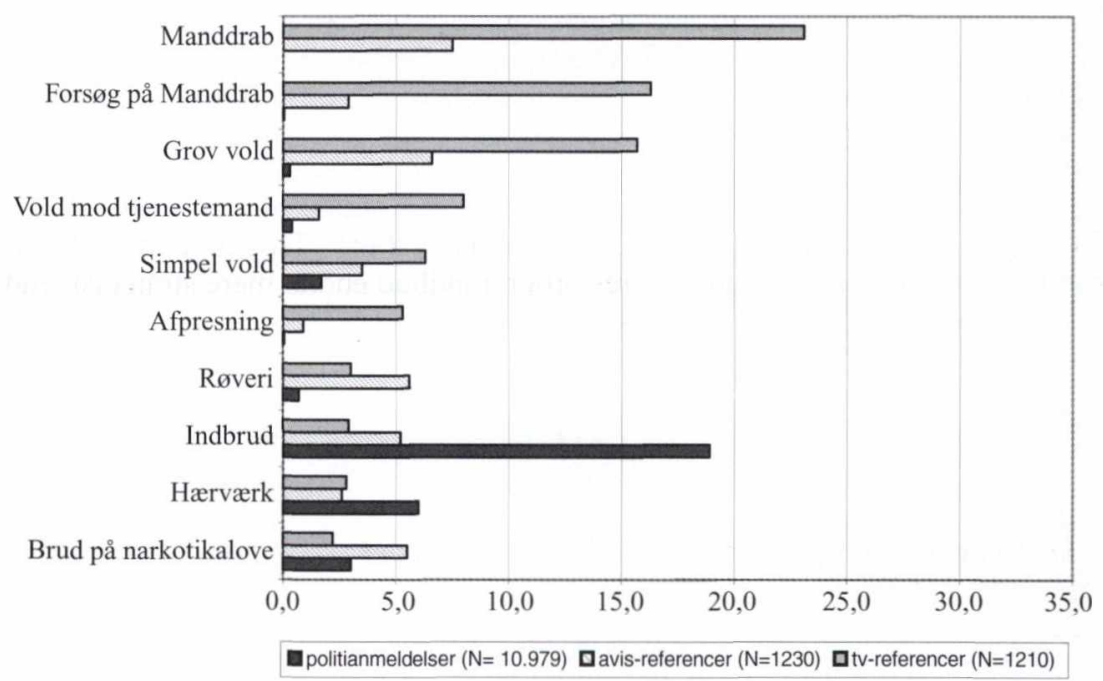


I den analyserede uge blev der i det dansktekstede tv-univers alt i alt begået 1.210 forbrydelser - heraf 280 mord og 200 mordforsøg. Vi registrerede små 100 eksempler på vold mod tjenestemand i funktion og 35 væbnede røverier. Desuden har vi fundet 2-300 eksempler på andre former for vold, som i det virkelige liv kunne falde ind under straffelovens paragraffer.

Sammenligner vi med Rigspolitichefens anmeldelsesregister for uge 46-2002 fremgår det, at tv-mediets voldelige tilbøjeligheder er stærkt overdrevne i forhold til det danske trusselsbillede, der tegnes af ugens politianmeldelser. Til gengæld underspiller tv-kanalerne kriminelle forhold som indbrud og brugstyverier samt de fleste former for white collar crime med afpresning som undtagelsen, der bekræfter reglen. Alt i alt modsvarer tv-kriminalitetens top-ti kun 31 procent af de forbrydelser, der i ugens løb er blevet meldt til dansk politi.

Når der vises kriminalitet på de dansksprogede tv-kanaler er det altså ikke primært et realistisk hverdagsscenario, der oprulles. I stedet inviteres seerne ind $i$ et voldeligt, amerikaniseret storby-univers, hvor mord og brand er en risiko, alle må kalkulere med. Alt $\mathrm{i}$ alt er 68 procent af de registrerede udsendelser med kriminelle indslag i dansktekstet tv af amerikansk oprindelse.

Hvad angår tv-nyheder indgår omtale af kriminalitet gennemsnitligt i hver anden udsendelse. Det kan lyde af meget. Men da hvert nyhedsprogram gennemsnitligt består af 10 indslag, udgør kriminaldækningen kun 5 procent af fjernsynets samlede nyhedsformidling i Danmark. Der er sjældent stærke billeder med blå blink og drama i danske kriminalsager, så ofte henvises den slags nyheder til de såkaldte kni- og knu-blokke: korte nyheder fra ind- og udland.

De fleste tv-nyheder af kriminel art er allerede blevet rapporteret af journalister knyttet til den trykte presse og formidlet videre gennem nyheds- og billedbureauer. Når man vil vurdere prioriteringen af dagsaktuelle forhold i relation til danske forbrydelser og deres opklaring, leverer tv således kun i begrænset omfang nye informationer, hvorimod aviser og nyhedsbureauer producerer hovedparten af den originale nyhedsdækning.

\section{Kriminalitet i ni danske dagblade}

I hverdagen leverer det nationale nyhedsbureau, Ritzau, en væsentlig del af dansk kriminaljournalistik baseret på rundringninger til landets politikredse. Dette fællesstof bliver derefter omsat til mindre noter eller råstof i større nyhedsartikler til dagens aviser. I prioriteringen spiller det kuriøse og sensationelle en væsentlig rolle. Det journalistiske arbejdet med notestoffet har ikke høj prestige på redaktionerne. Til gengæld viser dansk medieforskning, at dagbladenes kriminalnoter bliver flittigt læst (Poulsen, 1996).

Alt i alt omtaler ni danske dagblade i den analyserede periode 1.230 forbrydelser fordelt på 1.060 journalistiske artikler og debatindlæg. Vægtningen af notestoffet betyder, at kriminalitet i overvejende grad er politistof med døgnrapporten som hovedkilde. Politifolk indgår således som kilder i 29 procent af 
artiklerne - heraf $i$ tre fjerdedele af tilfældene som enekilde.

Andre myndighedsudøvere optræder i den analyserede uge i 7 procent af avisartiklerne, som rummer kriminalstof, mens politikere fra kommuner, amter og folketing høres i 9 procent af artiklerne. I modsætning til politi-kilderne optræder politiske repræsentanter kun som enekilde i en femtedel af de artikler, hvor der citeres folkevalgte.

Ingen andre interessenter opnår deltagelse $\mathrm{i}$ mere end to procent af avisartiklerne om kriminalitet. Vi har i den analyserede uge kun registreret tre dagbladscitater fra dommere, og ikke en eneste fra fængselsfunktionærer. Kriminologer og andre forskere er repræsenteret med 25 citater. Forsvarsadvokater og anklagere er ligeligt repræsenteret med henholdsvis 20 og 21 referencer. Anklagede og dømte høres i 22 tilfælde, ofre for forbrydelser ligeledes i 22 tilfælde, mens identificerbare vidner til forbrydelser citeres i 16 artikler.

Tabel 2. Redaktionelle enheder med kriminelt indhold i ni danske dagblade, uge 46-2002

noter nyhedsartikler debat i alt

Omnibusaviser:

Jyllands-Posten

Berlingske Tidende

Politiken

53

35

38

67

67

36

23

B.T.

\section{Lokalaviser:}

Fyens Stiftstidende

Fyns Amtsavis

99

55

473

I alt
35

49

41

13

22

21

111

100

100

100

20

13

84

17

63

61

160

58

36

117

84

28

15

198

84

405

182

1060

De tre landsdækkende omnibusaviser har alle specialiserede kriminalredaktioner, der dækker forbrydelser og ulykker - blandt danske journalister kaldet "112-stoffet". Tidligere var der også specialmedarbejdere, som dækkede den dømmende magt. Men lønningerne er blevet så tyngende, at ingen dansk avis i dag har råd til en fast journalist posteret ved domstolene. Det originale retsstof findes derfor stort set ikke i danske aviser - med mindre en enkeltsag bliver så 
spektakulær, at den får karakter af landsdækkende pligtstof (Nørgaard, 2001)

Hvad angår den procentvise andel, som kriminaldækningen udgør af ugens samlede redaktionelle stofmængde, ligger omnibusaviserne på nogenlunde samme niveau: Jyllands-Posten (12 procent), Politiken (13 procent) og Berlingske Tidende (12 procent). Ensartetheden slår også igennem på indholdssiden. Det er i det store og hele de samme kriminalsager, der tages op i de tre landsdækkende omnibusaviser.

Afhængigheden af nyhedsmediernes fællesstof er endnu mere markant i de to trafikaviser, Urban og MetroXpress, hvor næsten alle ugens artikler om kriminelle forhold har nyhedbureauet Ritzau som kilde. Relativt set prioriteres 112stoffet højt i gratisaviserne, idet andelen her er 18 procent af det samlede stof $\mathrm{i}$ MetroXpress og 17 procent i Urban.

Hvis man leder efter originaljournalistik af forbryderisk art, er det tilrådeligt at søge oplysning og underholdning i de to tabloidaviser, B.T. og Ekstra Bladet, hvor kriminalprocenten er henholdsvis 17 og 31 procent af det samlede stof. Begge aviser er afhængige af løssalg. Så der gøres meget ud af forsiderne i håb om at producere en såkaldt "kioskbasker". I den analyserede uge var der imidlertid hverken i B.T. eller Ekstra Bladet en eneste tophstorie, som havde kriminalitet $\mathrm{i}$ traditionel forstand som bærende element. Det nærmeste, forsiderne kom, var krav om at kriminalisere omskæring af muslimske piger. Men i den forbindelse vinkles mere på seksualitet og etnicitet end lov og orden i snæver forstand.

Heller ikke lokalaviserne prioriterer kriminalhistorier på forsiden. Når kriminalitetsandelen i Fyens Stiftstidende når op på 13 procent og Fyns Amts Avis på 10 procent, hænger det derimod sammen med flittig brug af kriminal-noter på lokalsiderne. Her er ingen forbrydelse tilsyneladende ligegyldig - hvis den vel at mærke foregår lokalt og meldes til politiet, så begivenhederne registreres i politiets døgnrapport. Denne redaktionelle vinkling medfører, at hverdagsforbrydelser har en klar overvægt i lokalpressen og bidrager dermed til at placere gement tyveri på en andenplads i den samlede opgørelse af kriminalitet i danske dagblade. 
Figur 3. Top-ti over kriminelle handlinger prioriteret ved antal referencer i ni dagblade sammenlignet med politianmeldelser og referencer i ni tv-kanaler, uge 46-2002 (i procent)

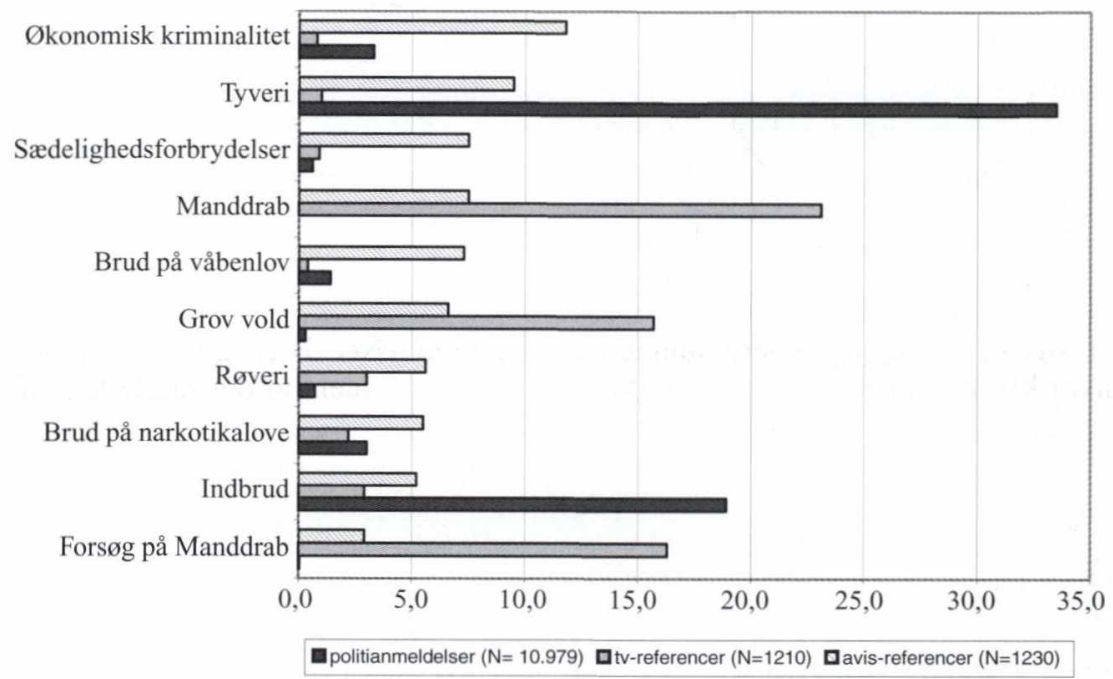

Sammenlagt for de ni danske dagblade kommer kategorien økonomisk kriminalitet på førstepladsen i uge 46, 2002. Forbrydelser som dokumentfalsk, bedrageri, mandatsvig og overtrædelse af særlove (bl.a. skattekontrolloven, momsloven, kildeskatteloven $\mathrm{m} . \mathrm{fl}$ ) făr markant højere prioritet på dagbladsredaktionerne end i tv og i politianmeldelserne.

Også sædelighedsforbrydelser opnår væsentlig større opmærksomhed blandt dagbladsjournalister, end tilfældet er i anmeldelsesregisteret og på tv. Det gælder vel at mærke ikke kun i løssalgsaviserne B.T. og Ekstra Bladet. Også de øvrige dagblade sætter voldtægt og andre former for seksuelle overgreb højt ved prioritering af hverdagens kriminaldækning.

Samlet set modsvarer dagbladsdækningen top-ti 66 procent af anmeldelsesregisterets indberetninger. Så alt andet lige afspejler avisernes dækning af disse samfundsforhold bedre end tv-prioriteringen den faktiske kriminalitet i Danmark - målt som antal anmeldte forbrydelser.

\section{Mediekriminalitet på den politiske dagsorden}

Summa summarum præsenterer danske tv-kanaler i en gennemsnitlig uge 16 procent udsendelser med kriminelle tilbøjeligheder - alt iberegnet. For dagbladsuniverset som helhed udgør kriminalstoffet 14 procent. I begge medietyper 
udgøres hovedparten af enkeltstående begivenheder, der ikke umiddelbart sætter retspolitiske spor. Deciderede debatindlæg, d.v.s. ledende artikler, kommentarer og læserbreve, udgør knapt en femtedel af kriminalstoffet i danske dagblade, og principielle tilkendegivelser af retspolitisk art udgør mindre end 2 procent af de registrerede indslag i de dansksprogede tv-kanaler.

Den relativt lave prioritering af debatindlæg er ikke nødvendigvis ensbetydende med, at medierne ingen indflydelse udøver på den politiske dagsorden. Det er således karakteristisk, at offentlig debat i Danmark i høj grad styres af den aktuelle nyhedsstrøm, og at de analyserede nyhedsmedier tenderer mod at fokusere på de samme emner i en given periode. Derved bliver spektakulære mediesager punktvis dagsordensættende, fordi autoriteter og folkevalgte føler sig kaldet til at formulere reaktioner af politisk og administrativ art på baggrund af den journalistiske dækning (Lauersen, 2001).

I den analyserede uge er der to emner, der på dagsordensættende vis dominerer debatten og derved på eksemplarisk vis illustrerer nyhedsmediernes politiske indflydelse: For det første krav om kriminalisering af omskæring af piger affødt af konkrete eksempler blandt somaliske indvandrere. For det andet krav om afkriminalisering af peber-spray, som omfattes af den danske våbenlovgivning, men $\mathrm{i}$ andre lande er et legalt accepteret middel til selvforsvar.

Forløbet af omskærings-debatten følger nøje det mønster, som både kriminologer og medieforskere betegner som "moralsk panik" (Cohen, 1973; McRobbie et al., 1995). Det faktuelle grundlag for sagen er diskutabelt og grundlaget følelsesladet - gødet af tidligere begivenheder. Frygt for ( $\mathrm{g}$ forargelse over) fremmedartede normer og skikke blandes sammen med krav om lov og orden. Den journalistiske dækning afføder læserbreve for og imod kriminalisering. Myndighederne fremstår handlingslammede, hvilket forstærker mediernes pres på det politiske system for at få skærpet regelsættet. Den politiske effekt bliver i dette tilfælde, at regeringen fremsætter lovforslag om skærpede sanktioner.

Hvor den journalistiske hovedvinkel på omskæring er beskyttelse af det enkelte individ i en kulturel konflikt, tematiseres krav om legalisering af peberspray som individuel risiko og mulighed for selvforsvar. Også denne sag havner på den politiske scene efter publikumsreaktioner, der af medierne betegnes som en "læserbrevsstorm". Igen er den umiddelbare effekt, at toneangivende politikere tager initiativ til at ændre lovgivningen i form af det, som i politisk-administrativ sammenhæng er blevet betegnes som "hovsaløsninger" og "enkeltsagspolitik" (Hornbech, 1997).

Den journalistiske sagsbehandling viser, at nyhedsmedierne er i stand til at placere et emne på den politiske dagsorden med krav om handlen fra de ansvarlige myndigheder. Men samtidig er der grund til at advare mod overvurdering af langtidseffekten ved sådanne enkeltsager. Det hører til sjældenhederne, at fokuseret medieomtale på længere sigt fører til ændringer af retspolitisk art - med mindre der er autoritative kilder, som kan benytte enkeltsagen til egne formål. 
Så selvom mediehistorier om afvigere fra normerne er reglen snarere end undtagelsen i moderne nyhedsjournalistik, bliver konsekvensen af den daglige rutineomtale af små og store forbrydelser grundlæggende en cementering af gældende normer for lov og ret. Konkrete magtanalyser viser, at rutinejournalistikken hviler solidt på præmisser for borgerlig normalitet. Udgangspunktet er konsensus gennem dækning af konflikter med nationalt fællesskab, individuelle frihedsrettigheder og lighed i forvaltningen som journalistiske præmisser (Lund, 2002).

Dybest set handler begge de medieprioriterede sagsforløb om, hvor meget folk bosat i Danmark kan afvige fra gældende normer uden at sætte sig uden for det nationale fællesskab. Afgørende for nyhedsmediernes politiske indflydelse er, at andre aktører løber med. Det er altså ikke nok, at der formidles noget nyt. Det faktuelle indhold skal også kunne bekræftes og følges op af andre end initiativtageren selv gennem anvendelse af redaktionelle rutiner præget af genbrug, fredelig kappestrid og tapning af de løbende nyhedskilder (Sparre, 2002).

Gennem rutinejournalistikken forankres hævdvundne normer for ro og orden. Professionelle journalister løber helst ikke efter de andres mediers solohistorier, med mindre man kan finde egne kilder eller originale vinkler på enkeltsagerne. Nyhedsmediernes politiske indflydelse kan derfor ikke kun måles på grundlag af det, journalisterne vælger at offentliggøre. Analysen må også inddrage de mange forhold, som henvises til tavshedens tusmørke. På trods af høj journalistisk produktivitet dækkes kun en brøkdel af de udspil og hændelser, som har betydning for kriminaliteten i samfundet. Af de begivenheder, der faktisk dækkes, ender en stor del som solo-nolo historier, der ikke bearbejdes af den samlede nyhedsinstitution. Det gælder især de mange noter i lokalaviserne.

Med en spidsformulering kan den journalistiske magtudøvelsen anskues som tilsløring gennem afsløring, idet den rutinemæssige hverdagspraksis skjuler ufatteligt meget ved at sætte afklarende fokus på relativt lidt. Derved defineres, hvilken afvigende adfærd, der kræver politisk regulering, mens resten af de aktuelle normbrud overlades til rutineadministration under konsensus-politikkens stiltiende accept. Nyhedsmedierne udøver derved punktvis en selvstændig magt, men påvirkes samtidig selv i endnu højere grad af andre magthavere, bl.a. som følge af den journalistiske afhængighed af politiets døgnrapporter.

Hertil kommer, at journalister og redaktører kun undtagelsesvis kan bestemme, hvad publikum skal mene. Til gengæld er mediedækningen i høj grad med til at bestemme, hvad politiske autoriteter skal mene noget om. Nyhedsugens data viser, at der ikke er tale om tvang eller hegemonisk medie-vælde. Som hovedregel indgår redaktionel magtudøvelse i rutineprægede beslutningsprocesser på basis af alment accepterede præmisser. Der er tale om gensidighed og samspil med konfliktende aktører (Jensen, 1981; Kvam, 2002: Welch et al., 1997), så man skal være forsigtig med at konkludere entydigt om magtrelationernes styrke og struktur (Mathiesen, 1986). 


\section{Kriminalitet som underholdning}

Vore analyser viser, at massemediernes kriminaldækning i hverdagen er præget af rutinejournalistik og afhængighed af autoritative nyhedskilder. Når der alligevel punktvis kan tales om udøvelse af redigerende magt, beror denne indsats især på, hvilke aspekter af kriminologisk art, der ignoreres eller prioriteres redaktionelt. Hertil kommer den massemedierede baggrundsstøj i form af sammenblanding af fakta og fiktion, der i stigende grad sætter sit præg på de dele af medieudbuddet, som traditionelt betragtes som uforpligtende underholdning.

Kriminelle handlinger er en veletableret form for underholdning både i dagblade og i tv (Kendrick, 1991; Zerlang, 1989). Ikke desto mindre tyder indholdsanalyserne foretaget i uge 46, 2002, på, at de vagthavende redaktører i Danmark ikke prioriterer dette stof særligt højt sammenlignet med andre stofområder. Det er således tankevækkende, at det meste af den tv-formidlede kriminalitet foregår i de sene nattetimer og sidst på eftermiddagen - altså ikke i den periode, hvor hensynet til seertal og reklameindtægter er størst. Det er også mange år siden, at en blodig kriminalhistorie på forsiden kunne øge salget af tabloidaviser væsentligt (Mortensen, 1973). Tidligere var det god latin, at der altid var salg i kriminalitet. Men sådan er det tilsyneladende ikke mere. Noget tyder på, at programlæggerne ikke betragter kriminalstof som det mest salgbare, og den slags vurderinger baseres vel at mærke på grundige publikumsanalyser af hensyn til annoncørerne.

Til gengæld indgår kriminelle handlinger nu rutinemæssigt i mediedækningen af en lang række emner ud over 112-stoffet i snæver forstand. I den sammenhæng bliver tv-universet af særlig interesse, når samspillet mellem medier og kriminalitet skal vurderes. Her er skellet mellem fakta og fiktion ikke længere så skarpt som tidligere. Der arbejdes systematisk med blandingsformer af typen reality-tv, dramadok og faktion (Larsen, 2002). I Danmark har det bl.a. resulteret $\mathrm{i}$ en ophedet debat om tv-serierne "Historier fra en politistation" og "Rejseholdet" (Bondebjerg, 2002). Sidstnævnte blev i foromtalerne betegnet som fiktion "based on a true story", og blandt danske journalister gik der sport i at gætte, hvilke autentiske kriminalsager, episoderne var inspireret af.

Fakta og fiktion blandes også systematisk i de populære "Sagen Uopklaret"serier, hvor tv hjælper myndighederne med at løse kriminalgåder på en underholdende måde. Begrundelsen for sådanne satsninger er potentiel samfundsnytte $\mathrm{i}$ form af effektive efterlysninger og generalprævention gennem konkret dækning af afvigende adfærd. Massemediernes kriminal-underholdning legitimeres som en public service, der tjener til at bekræfte fællesskabets normer og bevidstheden om, at den sociale orden grundlæggende er stabil og retfærdig.

Til det formål er massemedierede kriminalsager vel at mærke ikke det eneste middel - og næppe heller det ubetinget mest underholdende. Sportsdækningen kan siges at tjene samme formål. Det samme gælder journalistiske stofområder som etniske minoriteter og dækningen af forskellige typer af sundhedsrisiko, 
der er i kraftig vækst i danske massemedier (Lund, 1998). Hertil kommer, at vi på grundlag af de data, som er fremlagt her, kan argumentere for, at kriminaldækningens kerne - lov og orden - i høj grad påføres konkurrence fra andre typer af underholdende mediefortællinger.

\section{Figur 4}

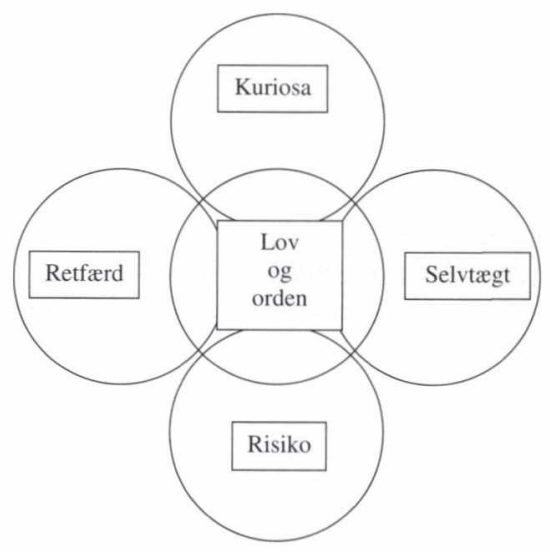

På nyhedsområdet drejer det sig primært om kuriositeter, f.eks. historier af arketypen mand bider (politi)hund. Her indgår kriminalitet som anledning til at fortælle en mærkværdig historie - uden at der rejses krav om håndhævelse af lov og orden. I tv-fiktionen kan en tilsvarende tendens iagttages i de populære ungdomsserier. Kriminalitet indgår som sidetema og spændingsskabende element, men det er sjældent mediefortællingernes hovedtema, og det er ikke givet, at retfærdigheden sker fyldest.

Den anden dominerende tendens på nyhedsområdet kan derimod betegnes som moraliserende retfcerdshistorier: Her er bl.a. tale om dramaer i amerikanske retssale og hjemlige krav om skærpede straffe, f.eks. kriminalisering af omskæring. I disse tilfælde nøjes massemedierne ikke med at dække kriminelle forhold og politiets opklaringsarbejde, men tematiserer målrettet uretfærdighed og oversete former for normbrud baseret på spektakulære enkeltsager. Eller sagt på en anden måde: I retfærdighedens navn produceres nye forbrydere og lovovertrædelser på en underholdende og politiserende måde.

Retfærdshistorierne findes også i underholdningsindustriens fiktionsunivers. Men de er dog langt fra enerådende i moderne tv. Den klassiske politi-serie og detektiv-krimier bliver i stigende grad udkonkurreret af action-underholdning med fokus på selvtcegt. Denne fortælleform kendes i rendyrket form i westerngenren. Men i tv-fiktionen møder vi nu også andre hævnere i slipstrømmen fra 
filmhelte som Dirty Harry og Rambo. Her er det ingen given præmis, at ordenshåndhævelse skal baseres på lov og ret. Tværtimod er neurotiske gangstere, korrupte eller uduelige politifolk og magtesløse myndigheder reglen snarere end undtagelsen. Den underholdende pointe er ofte, at der slet ikke kan forventes nogen social retfærdighed: Enhver må tage sin skæbne i egne hænder og træffe sine individuelle forholdsregler.

Den rationelle opdager af Sherlock Holmes typen (Porter, 1981) har tilsyneladende helt udspillet sin rolle i dette libertære underholdningsunivers. I de toneangivende medier tematiseres kriminalitet i stedet som en risiko i hverdagen, som kan dukke overalt og derved ramme alle og enhver. Sådanne risiko-historier er ikke blot en variant af massemedierede selvtægt-fortællinger, men åbner selvstændige muligheder for dramatisering af skyld og frygt. Som underholdningsgenre og nyhedsformat pålægger risiko-dramaturgien bl.a. ofre for kriminalitet et betydeligt ansvar for egen skæbne under angstprovokerende omstændigheder.

Tankevækkende nok konvergerer massemediernes action-thrillers med en markant tendens inden for nyere kriminologi (Borch, 2002). Begge steder opfattes risiko og selvtægt i stigende grad som centrale referencerammer, der tematiserer forbrydelser som et rutinepræget hverdags-fænomen - både i forskning og fiktion. Der lægges op til en situationel opfattelse af lovbrud, hvor den enkelte pålægges medskyld og individuelt forpligtes til at minimere sin personlige risiko.

Der er langt fra et sådant aktuarisk risiko-perspektiv på social uorden til idealiserede forestillinger om et velordnet retssamfund med normbrud som sociopatiske undtagelser knyttet til særlige personlighedstyper eller sociale miljøet. Til belysning af modsætningsfyldte sammenhænge mellem individuel angst og kollektiv ansvarsplacering forekommer subjektive risiko-analyser (Breck, 2001; Ungar, 2001) at være et forsømt forskningsfelt, som burde tages mere systematisk op af kriminologer og medieforskere i fællesskab.

Indholdsanalyser af den type, som er blevet præsenteret her, kan således ikke uden opfølgning med andre forskningsmetoder sige noget entydigt om den faktiske reception af massemedieret kriminalitet. Vi kan hverken entydigt af- eller bekræfte, om den aktuelle mediedækning genererer angst for kriminalitet (Balvig, 1978; Williams \& Dickinson, 1993) eller tværtimod fungerer uforpligtende eller tryghedsskabende i form af kompensatorisk handlinger per stedfortræder (Jerslev, 1999; Liska \& Baccaglini, 1990). På det foreliggende forskningsgrundlag må vi i første omgang nøjes med at konstatere, at det kriminalitetsbillede, som præsenteres i danske massemedier, kun i begrænset omfang modsvarer den faktiske kriminalitet - målt som antallet af anmeldelser af konkrete forbrydelser.

Denne hovedtendens bekræfter i det store og hele tilsvarende sammenligninger foretaget på tidligere tidspunkter i andre nordiske lande (Dahlgren, 1987; 
Höijer, 1994; Christofferson m.fl., 1997). De kvantitative resultater bliver imidlertid først for alvor interessante for praktisk journalistik og kriminologisk refleksion, hvis vi - som skitseret i artiklen her - indholdsanalytisk kobler de tre sociale virkelighedsbilleder (politianmeldelser, dagbladsjournalistik og tv-produktion) med henblik på kvalitativt at belyse det komplekse samspil mellem forskellige medier og fortælleformer - herunder vægtningen af fakta og fiktion.

I den forbindelse bliver uforpligtende underholdning en ganske alvorlig sag. Ikke kun fordi publikum muligvis lader sig påvirke af de fortællinger, der præsenteres gennem presse, radio og tv. Men også fordi massemediernes redaktionelle sammenblanding af fakta og fiktion gør det vanskeligt for ansvarlige beslutningstagere at skelne mellem den aktuelle uorden i samfundet, befolkningens angst for kriminalitet og repræsentativiteten af de massemedierende risikohistorier. Derved kan kriminalitet som underholdning indirekte få retspolitisk indflydelse og i konkrete beslutningsprocesser blive lige så dagsordensættende som kritisk forskning og systematisk kriminalstatistik.

Note:

En forskningsbevilling fra Justitsministeriet har gjort det muligt systematisk at registrere indslag og artikler af kriminel art i udvalgte dele af det danske massemedier. For dagbladenes vedkommende er der anvendt systematisk indholdsanalyse (Lund, 2000:7-9). Kodningen er gennemført af fire rutinerede journaliststuderende: Thomas Bach-Laursen, Eva Balslev, Inge Lise Skrydstrup og Sys Christina Vestergaard. Alle artikler, hvori der forekommer reference til kriminelle handlinger, er blevet registreret efter medie, ugedag, tematisering, anledning, genre, kategorisering (i henhold til Rigspolitiets anmeldelsesregister), optælling af kriminelle handlinger og eksplicitte kilder - herunder mediedefinerede roller og køn. Rådata foreligger på maskinlæsbar form (SPSS). Der har desværre ikke været økonomi til en tilsvarende systematik på tv-området. Her har fremgangsmåden været, at kortlægge de ni sendeflader ved hjælp af udbydernes programoversigter. Derefter er selekteret stikprøver af enkelte udsendelser udvalgt strategisk i forventning om fund af kriminel art. Desuden har koderne i ugens løb ført logbog over deres normale tv-forbrug med henblik på afdækning af oversete krimi-aspekter. På den baggrund må de konklusioner, der primært baseres på tv-materialet, vurderes med forsigtighed, da de sammenfattende totalopgørelser kan være behæftet med systematisk bias, idet denne del af undersøgelsen i sidste instans beror på kvalitative skøn baseret på strategisk udvalgte stikprøver.

\section{LITTERATUR}

Balvig, F. (1978): Angst for kriminalitet: Lov-og-orden tendenser i en dansk provinsby. København: Gyldendal.

Borch, C. (2002). Kriminalitet og kriminelle - brudstykker af en genealogi. Tidsskriftet Dansk Sociologi 13(1):57-72.

Bondebjerg, I. (2002): Med politiet i 'virkeligheden': Reality-tv og kriminalitet. Tidsskriftet MedieKultur 34:62-77.

Breck, T. (2001): Dialog om det usikre - nye veje i risikokommunikation. København: Akademisk Forlag.

Christofferson, J. et al. (1997): Argument i repris : pressdebatten om medievåld. Stockholm: Våldsskildringsrådet.

Clausen, S. (2002): Terrorangrebet på USA og bekymring for kriminalitet. Nordisk Tidsskrift for Kriminalvidenskab 89:16-26. 
Cohen, S. (1973): Folk Devils and Moral Panics. St. Albans: Paladin.

Cohen, S. \& Young, J. (1973). The Manufacture of News: Social Problems, Deviance and the Mass Media. London: Constabale.

Critcher, C. (2002): Media, Govenmnent and Moral Panic: The Politics of Paedophhilia in Britain. Journalism Studies 3:512-535.

Cronström, J. (1999): Gränslöst : om tv, våld och ansvar: Stockholm: Våldsskildringsrådet.

Dahlgren, P. (1987): Pressens bild av brottsligheten. Stockholm: BR $\AA$-Information.

Dalquist, U. (1998): Större våld än nöden kräver? Medievåldsdebatten i Sverige 1980-1995. Umeå: Boréa Bokförlag.

Drotner, K. (2001): Medier for fremtiden. København: Høst \& Søn.

Erstad, O. (1998): Den offentlige angst : betraktninger om statlige initiativ mot vold $i$ billedmediene. Norsk medietidsskrift 2:5-18.

Feilitzen, C. (2001): Medievåldets påverkan: en kortfattad forskningsöversikt. Göteborg: NORDI$\mathrm{COM}$.

Frøbert, K.Aa. (2000). Massemediernes frihed og ansvar. København: Greens Jura.

Gadd, P. (1994): Mord, Blod och Moral. Om kriminaljournalistik. Stockholm: Carlssons.

Goode, E. \& Ben-Yehuda, N. (1994): Moral Panics: The Social Construction of Deviance. Oxford: Blackwell.

Hornbech, B.R. (1997): Så gik der politik i det ... Folketinget under anklage. København: Gyldendal.

Höijer, B. (1994): Våldsskildringar i TV-nyheter. Produktion, utbud, publik. Stockholm: Våldsskildringsrådet.

Høst, S. \& Bodahl-Johansen G. (2001): Kulturforskjell og tilpasning: Journalisters forhold til politi, patalemyndighet og domstoler. Oslo: Institutt for Journalistikk.

Jensen, B. (1981). Kriminalreporter - en dokumentarisk interview- og debatmontage om kriminalitet, mennesker og samfund. Horsens: Forlaget Ålykke.

Jerslev, A. (1999): Det er bare film: Unges videofallesskaber og vold på film. København: Gyldendal.

Kendrick, W. (1991): The Thrill of Fear: 250 Years of Scary Entertainment. New York: Grove Press,

Kvam, B. (2002). Krimjournalisten. Oslo: IJ-forlaget.

Kvam, B. \& Røssland, L.A. (1998): Tilfeldig gapestokk: pressens identifisering i kriminalsaker. Bergen: John Grieg forlag.

Larsen, P.H. (2002): Virkeligheden på spil: Iscenescettelse af virkeligheden i tv-programmer - fra journalistik til underholdning. Tidsskriftet MedieKultur 34:78-91.

Lauersen, S. (2001): Vold på dagsordenen - Medierne og den politiske proces. Århus: Magtudredningen.

Liska, A.E. \& Baccaglini, W. (1990). Feeling Safe by Comparison: Crime in the Newspapers. Social Problems 37:360-374.

Lund, A.B.(1998): Smitsomme sygdomme i dansk journalistik. København: Munksgaards Forlag.

Lund, A.B. (2000): Først med det sidste - en nyhedsuge i Danmark. København: Forlaget Ajour.

Lund, A.B. (2002): Den redigerende magt-nyhedsinstitutionens politiske indflydelse. Århus: Aarhus Universitetsforlag.

Lund, A.B. \& Horst, M. (1999): Den offentlige debat - mål, middel eller mantra? København: Forlaget Fremad.

Mathiesen, T. (1986): Makt og medier - en innføring i mediesosiologi. Oslo: Pax.

McRobbie, A. \& Thornton, S. (1995): Rethinking 'Moral Panic' for Multi-Mediated Social Worlds. British Journal of Sociology 46:559-574.

Mortensen, F. (1978): Sex og vold - det saelger da hver gang. Tidsskriftet Bidrag 9(10):209-256.

Mustonen, A. (1997): Media violence and its audience. Jyväskylä: University of Jyväskylä.

Nørgaard, E. (2001). Journalist på rettens vej. Århus: Forlaget Ajour.

Pollack, E. (2001): En studie i medier och brott. Stockholm: JMK.

Porter, D. (1981): The Pursuit of Crime: Art and Ideology in Detective Fiction. New Haven: Yale University Press. 
Poulsen, J. (1996): Hvad ønsker lceserne? Roskilde: RUC-Kommunikationsuddaannelsen.

Rönnberg, M. (1998): Moralbilder: Om medieetik, våld och debattporr. Uppsala: Filmförlaget.

Schlesinger, P. \& Tumber, H. (1994): Reporting Crime. Oxford: Claredon Press.

Sparre, K. (2002): Politiet som kilder: Århus: Center for Journalistik og Efteruddannelse.

Sundholm J. \& Vartiainen P. (2001): Nationalising the International Crime Genre. Nordicom Review 22(1):97-104.

Ungar, S. (2001): Moral Panic versus the Risk Society: The Implications of the Changing Sites of Social Anxiety. British Journal of Sociology 52:271-291.

Walma, J.H. et al. (2002): Television News and Fear: Communications 27:303-217.

Williams, P. \& Dickinson, J. (1993): Fear of Crime: Read All about It? British Journal of Criminology 33:33-56.

Wykes, M. (2001): News, Crime and Culture. London: Pluto Press.

Zerlang, M. (1989): Underholdningens historie: Fra antikkens gladiatorer til nutidens TV-serier: København: Gyldendal. 